\title{
The Borg CR-10 scale is suitable to quantify aerobic exercise intensity in women with fibromyalgia syndrome
}

A escala CR-10 de Borg é viável para quantificar a intensidade do exercício aeróbio em mulheres com sindrome fibromiálgica

La escala Borg CR-10 es adecuada para cuantificar la intensidad del ejercicio aeróbico en mujeres con sindrome de fibromialgia

\author{
Carolina Pieroni Andrade', Antonio Roberto Zamunér ${ }^{2}$, Meire Forti ${ }^{3}$, Thalita Fonseca de França ${ }^{4}$, \\ Ester da Silva ${ }^{5}$
}

ABSTRACT | Patients with Fibromyalgia syndrome (FMS) report higher ratings of perceived exertion (RPE) compared to healthy individuals for the same exercise intensity; however, to our knowledge, no studies have evaluated RPE at the ventilatory anaerobic threshold (VAT) for this population. This study aimed to assess RPE using the Borg CR-10 scale during a cardiopulmonary exercise test (CPET) in women with FMS. Twenty-four women with FMS and twenty healthy control subjects (HC) voluntarily participated in this study. Near the end of every 1-minute period during CPET, subjects were asked to report their RPE for fatigue in the lower limbs (RPE-L) and dyspnea (RPE-D), respectively, according to the Borg CR-10 scale. FMS subjects showed higher RPE-L and RPE-D compared to HC subjects at free wheel and at the first load increment. However, no significant difference was observed between groups for power output. There was no significant difference between groups for RPE-L and RPE-D reported at VAT and peak CPET. However, FMS subjects showed lower power output compared to HC subjects. The present results showed that FMS subjects present higher RPE compared to HC subjects. However, RPE reported at VAT and at peak CPET was not different between groups. The Borg CR-10 scale scores obtained at VAT can be used as an additional parameter for prescribing exercise intensity in aerobic training protocols for women with FMS.

Keywords I Pain; Physical Fitness; Physical Exertion; Fibromyalgia.

RESUMO I Pacientes com síndrome fibromiálgica (SFM) relatam elevados níveis de percepção subjetiva de esforço (PSE) em comparação com indivíduos saudáveis para a mesma intensidade de exercício; no entanto, a nosso conhecimento, nenhum estudo avaliou a PSE no limiar de anaerobiose ventilatório (LAV) para essa população. Este estudo buscou avaliar PSE usando a escala CR-10 de Borg durante um teste de exercício cardiopulmonar (TECP) em mulheres com SFM. Vinte e quatro mulheres com SFM e vinte indivíduos saudáveis (GS) participaram deste estudo voluntariamente. Perto do final de cada período de 1 minuto durante CPET, os indivíduos foram convidados a relatar sua PSE para fadiga nos membros inferiores (PSE-MMII) e dispneia (PSE-D), respectivamente, de acordo com a escala CR10 de Borg. Os indivíduos com SFM mostraram maior PSE-MMII e PSE-D, em comparação com indivíduos GS tanto na carga livre como no primeiro incremento de carga. No entanto, não houve diferença significativa entre os grupos para a potência e nem para PSEMMII e PSE-D relatado no LAV e no pico TECP. No

\footnotetext{
Study developed at the Department of Physical Therapy of Universidade Federal de São Carlos - São Carlos (SP), Brazil.

'Pt, Department of Physical Therapy, Universidade Federal de São Carlos - São Carlos (SP), Brazil.

2PhD, Department of Physical Therapy, Universidade Federal de São Carlos - São Carlos (SP), Brazil.

${ }^{3} \mathrm{Ms}$, Department of Physical Therapy, Universidade Federal de São Carlos - São Carlos (SP), Brazil.

${ }^{4}$ Pt, Department of Physical Therapy, Universidade Federal de São Carlos - São Carlos (SP), Brazil.

${ }^{5}$ PhD, Department of Physical Therapy, Universidade Federal de São Carlos - São Carlos (SP), Brazil. 
entanto, indivíduos com SFM mostraram baixa potência em comparação com indivíduos GS. Esses resultados mostraram que indivíduos com SFM apresentam a PSE mais elevada em comparação com indivíduos GS. No entanto, a PSE relatada no LAV e no pico TECP não foi diferente entre os grupos. As pontuações de escala CR-10 de Borg obtidas no LAV podem ser usadas como um parâmetro adicional para a prescrição da intensidade de exercício nos protocolos de treinamento aeróbio para mulheres com SFM.

Descritores | Dor; Aptidão Física; Physical Exertion; Fibromialgia.

RESUMEN | Los pacientes con síndrome de fibromialgia (FMS) reportan índices más altos de esfuerzo percibido (RPE) en comparación con individuos sanos para la misma intensidad de ejercicio; sin embargo, a nuestro conocimiento, ningún estudio ha evaluado el RPE en el umbral ventilatorio anaeróbico (VAT) para estas personas. Este estudio tuvo como objetivo evaluar el RPE utilizando la escala Borg CR-10 durante un test de ejercicio cardiopulmonar (CPET) en mujeres con FMS. Veinticuatro mujeres con FMS y veinte individuos de control sanos (HC) participaron voluntariamente en este estudio. Cerca del final de cada período de 1 minuto durante el CPET, se pidió a los individuos que informaran su RPE para la fatiga en los miembros inferiores (RPE-L) y disnea (RPE-D), respectivamente, según la escala Borg CR-10. Los individuos con FMS mostraron mayores RPE-L y RPE-D comparados con los individuos HC en la rueda libre y en el primer incremento de carga. Sin embargo, no se observó diferencia significativa de potencia de salida entre los grupos. No hubo diferencias significativas entre los grupos en los RPE-L y RPE-D reportados en el VAT y en el máximo CPET. No obstante, los individuos FMS mostraron una menor potencia en comparación con los individuos HC. Los resultados actuales mostraron que los individuos con FMS presentan RPE más alto en comparación con los individuos HC. De todos modos, el RPE reportado en el VAT y en el CPET máximo no fue diferente entre los grupos. Las puntuaciones de la escala Borg CR-10 obtenidas en el VAT se pueden utilizarse como un parámetro adicional para prescribir la intensidad del ejercicio en protocolos de entrenamiento aeróbico para mujeres con FMS.

Palabras clave | Dolor; Aptitud Física; Esforço Físico; Fibromialgia.

\section{INTRODUCTION}

Fibromyalgia syndrome (FMS) is a noninflammatory rheumatic condition mainly characterized by widespread chronic pain ${ }^{1}$. In addition to pain, some authors suggest that these patients report higher ratings of perceived exertion (RPE) compared to healthy individuals for the same exercise intensity ${ }^{2}$. Thus, in combination with other common symptoms of FMS (e.g., pain, fatigue, joint stiffness, orthostatic intolerance) $)^{3,4}$, high RPE may contribute to low physical activity levels and low aerobic functional capacity observed in this population ${ }^{2,5-7}$.

Therefore, aerobic exercise has been recommended for the treatment of patients with FMS for its numerous benefits, such as reduced pain and increased aerobic functional capacity and better quality of life ${ }^{6}$. Moreover, according to Valim et al. ${ }^{5}$, low to moderate-intensity exercise should be prioritized instead of highintensity exercise, since the improvement of the aerobic functional capacity is not associated with improved symptoms. It is noteworthy that the ventilatory anaerobic threshold (VAT) better reflects the aerobic functional capacity of patients with FMS than the peak oxygen uptake $\left(\mathrm{VO}_{2 \text { peak }}\right)$, since these patients are usually not able to perform maximal exercise during cardiopulmonary exercise testing $(\mathrm{CPET})^{5}$.

Therefore, VAT is an important parameter for the assessment and prescription of exercise intensity, since it provides a homogeneous acute metabolic response to physical training stimulus for different individuals, and does not expose patients to the risk of high-intensity exercises ${ }^{8}$.

In this sense, some authors have proposed the Borg CR-10 scale as a complementary tool to determine the workload related to VAT ${ }^{9-11}$. In addition, RPE has been used to prescribe exercise intensity, especially during non-supervised exercises, as it increases the accuracy and assertiveness in keeping the prescribed exercise intensity $6,11,12$. Therefore, determining RPE corresponding to VAT and determining if the RPE behavior during incremental exercise test in women with FMS differs from healthy individuals is relevant to improve the effectiveness of non-supervised exercises for this population.

Based on the above, this study aimed to test the hypothesis that women with FMS show higher RPE compared to healthy women for relative exercise intensity, but not at specific moments of CPET such as VAT and exercise peak. 


\section{METHODOLOGY}

\section{Participants}

The study included 24 subjects with clinical diagnosis of FMS according to criteria established by the American College of Rheumatology ${ }^{1}$. Twenty healthy subjects who matched the FMS group for age, body mass index (BMI) and physical activity level (IPAQ) composed the healthy control group $(\mathrm{HC})^{13}$. Subjects who had history of cardiovascular, respiratory or metabolic disease of any kind, musculoskeletal abnormalities or inflammation as cause of pain, neurological disorder, smokers, or those engaged in regular physical activity were excluded from the study.

The study was approved by the Research Ethics Committee of the institution (Protocol 112 508) and all subjects signed the informed consent form.

\section{Study protocol}

All subjects were evaluated in the morning. The room temperature was maintained between $22^{\circ} \mathrm{C}$ and $24^{\circ} \mathrm{C}$ and relative humidity between $40 \%$ and $60 \%$. Subjects were familiarized with the experimental protocol and instructed to have a light meal two hours before the experiment. Subjects were also advised to abstain from stimulants and alcoholic beverages 24 hours prior to the evaluation, and not to perform strenuous exercise 48 hours before the experiment.

\section{CPET}

The CPET protocol was continuous ramp type performed in cycle ergometer with electromagnetic braking (Quinton Corival 400, Seattle, WA, USA) and with seat adjusted to allow about 5 to 10 degrees of knee flexion. Subjects were instructed to keep pedaling cadence at 60 revolutions per minute (rpm) and not to perform isometric contraction of upper limbs during the test.

CPET consisted of 1 minute at rest in the sitting position on the cycle ergometer, followed by 4 minutes of warm-up exercise at intensity of $4 \mathrm{~W}$ of power output (free wheel). Subsequently, power output increment protocol was initiated until physical exhaustion (exercise peak), defined as the time when subjects were unable to keep pedaling at $60 \mathrm{rpm}$ or until the manifestation of a limiting symptom (e.g., pain, dizziness, nausea) or respiratory fatigue ${ }^{10}$.
Power output increments were determined for each subject according to formula proposed by Wasserman et al. ${ }^{14}$ Power $(W)=([($ height - age $) .14]-[150+(6$ body . mass)])/100.

During CPET, electrocardiogram and heart rate (HR) were recorded beat by beat in real time using CardioPerfect ${ }^{\circledR}$ device (Welch Allyn CardioPerfect Workstation, Skaneateles Falls, NY).

At the end of CPET, three blinded experienced researchers determined VAT using the graphic visual method to estimate the disproportionate increase in ventilatory and metabolic variables during dynamic incremental exercise ${ }^{15}$. The criterion adopted was the loss of parallelism between $\mathrm{VO}_{2}$ and $\mathrm{VCO}_{2}{ }^{15}$.

\section{Recording ventilatory and metabolic variables}

$\mathrm{VO}_{2}, \mathrm{VCO}_{2}, \mathrm{VE}$, and respiratory exchange ratio (RER) were recorded on a breath-to-breath basis over CPET using an expired gas measurement system (Ultima PFX system, Medical Graphics, St. Paul, MN) calibrated before each test.

\section{Borg CR-10 Scale}

During familiarization session, each participant received instructions on the use of the Borg CR-10 scale including anchoring procedures ${ }^{16}$. Near the end of each 1-minute period during CPET, participants were asked to report RPE for fatigue in the lower limbs (RPE-L) and for dyspnea (RPE-D), respectively, according to the Borg CR-10 scale ${ }^{16}$.

\section{Statistical analysis}

To assess data normality, the Shapiro-Wilk test was used. For continuous variables, intergroup comparison was performed using the Student $t$ test for independent samples. For discontinuous variable "number of postmenopausal volunteers," the $\chi 2$ test was performed. The significance level for both tests was set at 5\%.

To compare RPE-L, RPE-D and power output between FMS and HC groups over CPET, 4 moments were analyzed: (1) free wheel (corresponding to the warm-up period of CPET); (2) first load increment (time that included the first minute after the start of the power increment); (3) VAT and (4) exercise peak. For the intergroup comparison at each of the 4 moments, the Mann-Whitney test was conducted. For intragroup 
comparison, the Friedman test was conducted. For both tests, a priori Bonferroni adjustment was performed, and $\mathrm{p}$-values $<0.01$ were considered significant. All analyses were performed using the software BioEstat5. $0^{\oplus}$.

\section{RESULTS}

Clinical data of FMS and HC groups are shown in Table 1. FMS had higher BMI compared to HC $(\mathrm{p}<0.05)$. No significant differences were observed for the other variables $(p>0.05)$.

Table 1. Age, anthropometric characteristics and baseline hemodynamic variables of fibromyalgia syndrome group (FMS) and healthy group $(\mathrm{HC})$.

\begin{tabular}{lrrr}
\multicolumn{1}{c}{ Variables } & HC $(n=20)$ & FMS $(n=24)$ & \multicolumn{1}{c}{$P$} \\
Age (years) & $46 \pm 7$ & $49 \pm 8$ & 0.11 \\
BMI (Kg/m $\left.{ }^{2}\right)$ & $24.7 \pm 3.0$ & $27.0 \pm 3.9$ & 0.006 \\
N postmenopausal & 12 & 13 & 0.93 \\
subjects & & & 0.97 \\
SBP (mmHg) & $117 \pm 12$ & $117 \pm 13$ & 0.62 \\
DBP (mmHg) & $66 \pm 7$ & $69 \pm 6$ & 0.45 \\
HR (bpm) & $66 \pm 8$ & $71 \pm 8$ &
\end{tabular}

Data presented as mean \pm standard deviation. N: number of volunteers; BMl: body mass index; SBP: systolic blood pressure; DBP: diastolic blood pressure; HR: heart rate.

Table 2 shows the cardiorespiratory variables obtained at VAT and peak CPET. FMS group presented lower relative $\mathrm{VO}_{2}$ compared to $\mathrm{HC}$ group at $\mathrm{VAT}(\mathrm{p}<0.05)$. At peak CPET, participants of FMS group presented lower $\mathrm{HR}$, relative $\mathrm{VO}_{2}$, absolute $\mathrm{VO}_{2}, \mathrm{VCO}_{2}$ and $\mathrm{VE}(\mathrm{p}<0.05)$.

Figure 1 shows RPE-L, RPE-D and power output obtained during CPET. FMS showed higher RPE-L and RPE-D compared to HC group at free wheel and at the first load increment $(\mathrm{p}<0.001)$. However, there was no significant difference between groups for power output $(\mathrm{p}>0.05)$.

At VAT and peak CPET, there was no significant difference between groups for RPE-L and RPE-D ( $p>0.05)$. However, FMS showed lower power output compared to $\mathrm{HC}(\mathrm{p}<0.001)$.

Regarding intragroup comparisons, both groups showed progressive increases in RPE-L and RPE-D along CPET. In HC, RPE-L and RPE-D reported at VAT and at exercise peak were higher compared to RPE-L and RPE-D reported at free wheel $(\mathrm{p}<0.01)$ and first load increment ( $p<0.01$ ). In FMS, RPE-L and RPE-D obtained at exercise peak were higher compared to values in situation with free wheel $(\mathrm{p}<0.01)$, first load increment $(\mathrm{p}<0.01)$ and at VAT $(\mathrm{p}<0.01)$. Moreover,
RPE-L and RPE-D reported at VAT were higher compared to situation with free wheel $(\mathrm{p}<0.01)$.

Table 2. Cardiorespiratory and metabolic variables obtained at ventilatory anaerobic threshold (VAT) and peak of the cardiopulmonary exercise test of fibromyalgia syndrome (FMS) and healthy control groups (HC).

\begin{tabular}{|c|c|c|c|}
\hline Variables & $H C(n=20)$ & FMS $(n=24)$ & $\mathbf{P}$ \\
\hline \multicolumn{4}{|l|}{ VAT } \\
\hline HR (bpm) & $112 \pm 15$ & $105 \pm 12$ & 0.09 \\
\hline $\mathrm{VO}_{2}\left(\mathrm{~mL} \cdot \mathrm{kg}^{-1} \cdot \mathrm{min}^{-1}\right)$ & $12.1 \pm 2.2$ & $9.5 \pm 2.8$ & $<0.001$ \\
\hline $\mathrm{VO}_{2}\left(\mathrm{~L} \cdot \mathrm{min}^{-1}\right)$ & $0.65 \pm 0.30$ & $0.65 \pm 0.19$ & 0.98 \\
\hline $\mathrm{VCO}_{2}\left(\mathrm{~L} \cdot \mathrm{min}^{-1}\right)$ & $0.63 \pm 0.20$ & $0.63 \pm 0.18$ & 0.97 \\
\hline RER & $0.97 \pm 0.01$ & $0.97 \pm 0.02$ & 0.81 \\
\hline$V E\left(L \cdot m^{-1}{ }^{-1}\right)$ & $21.8 \pm 3.40$ & $19.8 \pm 5.70$ & 0.14 \\
\hline \multicolumn{4}{|l|}{ PEAK } \\
\hline HR (bpm) & $148 \pm 12$ & $131 \pm 18$ & $<0.001$ \\
\hline $\mathrm{VO}_{2}\left(\mathrm{~mL} \cdot \mathrm{kg}^{-1} \cdot \mathrm{min}^{-1}\right)$ & $19.0 \pm 4.2$ & $14.8 \pm 3.6$ & $<0.001$ \\
\hline $\mathrm{VO}_{2}\left(\mathrm{~L} \cdot \mathrm{min}^{-1}\right)$ & $1.19 \pm 0.20$ & $1.00 \pm 0.20$ & 0.01 \\
\hline $\mathrm{VCO}_{2}\left(\mathrm{~L} \cdot \mathrm{min}^{-1}\right)$ & $1.37 \pm 0.30$ & $1.15 \pm 0.30$ & 0.03 \\
\hline RER & $1.17 \pm 0.09$ & $1.14 \pm 0.13$ & 0.38 \\
\hline $\operatorname{VE}\left(L \cdot \mathrm{min}^{-1}\right)$ & $43.8 \pm 12.5$ & $36.4 \pm 12.0$ & 0.05 \\
\hline
\end{tabular}

Data presented as mean \pm standard deviation. N: number of volunteers; VAT: ventilatory anaerobic threshold; Peak: peak cardiopulmonary test; HR: heart rate; SBP: systolic blood pressure; DBP: diastolic blood pressure; $\mathrm{VO}_{2}$ : oxygen uptake; $\mathrm{VCO}_{2}$ : carbon dioxide production; RER: respiratory exchange ratio; $\mathrm{VE}$ : ventilation.

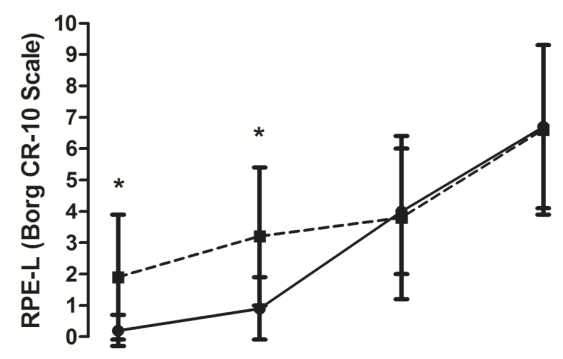

$\rightarrow \mathrm{HC}$

- FMS

(a)

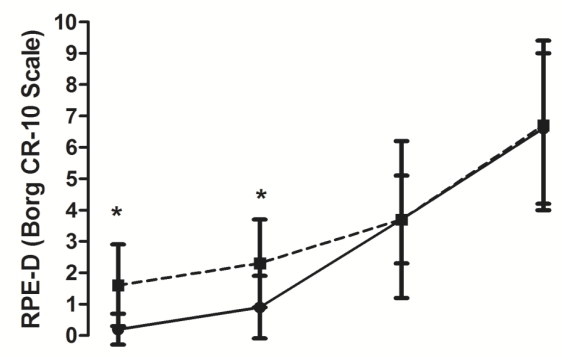

(b)

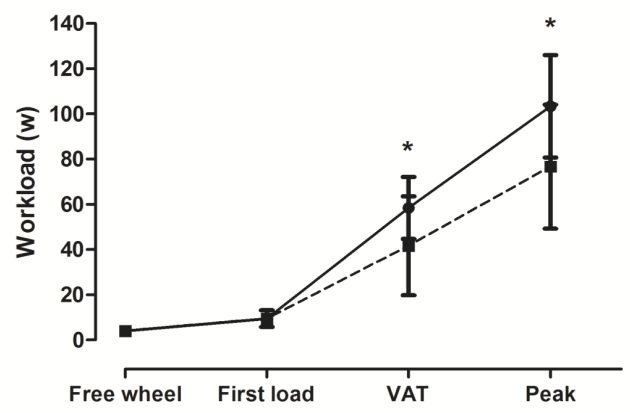

(c)

Figure 1. Ratings of perceived exertion for fatigue in the lower limbs (RPE-L) (a), dyspnea (RPE-D) (b) and power output (c) obtained at free wheel, first load increment, ventilatory anaerobic threshold (VAT) and peak of the cardiopulmonary exercise test. 


\section{DISCUSSION}

The main findings of this study showed that during CPET, RPE was higher in FMS group compared to $\mathrm{HC}$ group, both in situations with free wheel and in the first load increment. Moreover, RPE at VAT and exercise peak was not significantly different between groups. However, FMS presented smaller power output than $\mathrm{HC}$ at both moments (i.e., VAT and exercise peak).

Previous studies have reported that RPE in women with FMS is greater compared to healthy subjects during constant load testing ${ }^{2,17}$. The authors attribute this result to a possible overlap of the peripheral pain perception with the perceived exertion during exercise, increasing sensory stimuli from the musculoskeletal system and consequently $\mathrm{RPE}^{17}$.

Therefore, the amplification of sensory information from the musculoskeletal system during exercise may have hindered the discrimination of fatigue in lower limbs, dyspnea and pain sensation in the present study, resulting in increased RPE at free wheel and at the first load increment, since the power output was similar for both groups.

Another factor that may have contributed to this finding is possible different muscle recruitment in FMS group during exercise. Pierrynowski et al. ${ }^{18}$ observed during walking exercise that women with FMS use hip flexor muscles instead of plantar flexor muscles to enhance gait, which contributed to their perception of this activity as strenuous.

Interesting finding of this study was that although power output at VAT and exercise peak was different between groups, no significant differences between RPE-L and RPE-D were found. However, it has been shown that groups with different characteristics (e.g., male and female, active and sedentary, etc.) have similar RPE values at certain times of the exercise such as VAT and exercise peak ${ }^{9-11}$. The authors reported that the fact that RPE at VAT does not vary among individuals with different characteristics enables its use as complementary tool for physical exercise prescription.

Studies on RPE in patients with FMS are relevant since the misinterpretation of physical exertion (i.e., high perceived exertion for relatively low exercise intensities) may contribute to low physical activity levels and lower aerobic functional capacity, commonly observed in these patients. In this study, the results showed that FMS showed lower relative $\mathrm{VO}_{2}$, absolute $\mathrm{VO}_{2}$ and $\mathrm{VCO}_{2}$ values at peak CPET compared to healthy subjects. The impairment of the aerobic functional capacity in patients with FMS has been well documented in the literature ${ }^{2,5-7}$. Several factors may contribute to the low aerobic functional capacity in patients with FMS. Soriano-Maldonado et al. ${ }^{7}$ found an association between pressure pain threshold and aerobic functional capacity, indicating that the higher the pressure pain threshold, the greater the individual's ability to perform physical exercises. On the other hand, Valim et al. ${ }^{5}$ reported that in addition to sensory and metabolic dysfunction, the impairment of behavioral and cognitive functions should also be considered as potential factors that could contribute to the low aerobic functional capacity both at exercise peak and VAT.

VAT has been considered a physiological parameter internationally accepted for assessing the aerobic functional capacity and quantifying aerobic exercise intensity ${ }^{19}$. In addition, some authors have reported the importance of physical training at levels close to VAT ${ }^{8}$. Among the main advantages, the non-exposure of patients to the risks of high-intensity exercises, the lower risk of injuries and greater adherence to physical training protocols stand out. Moreover, VAT reflects better the aerobic functional capacity of patients with FMS than $\mathrm{VO}_{2 \max }$ or $\mathrm{VO}_{2 \text { peak }}$, since these patients are usually not able to perform maximal exercise during CPET $^{5,6}$.

The lack of significant difference between groups for $\mathrm{RPE}$ at VAT and exercise peak suggests that RPE reflects the physiological responses to the increasing exercise intensity regardless of the absolute values of power output. $\mathrm{RPE}$ processing during physical activity results from the integration of multiple afferent signals of sensory receptors located in active skeletal muscles and cardiopulmonary system $^{20}$. These structures can be stimulated by metabolic acidosis associated with decreased blood and muscular $\mathrm{pH}^{21}$. Thus, an increase in efferent neuromotor activity should occur to compensate for the peripheral fatigue resulting from contractile failure, which also modulates perceived exertion ${ }^{14}$. Thus, the higher the intensity of the effort, the greater the RPE.

Considering that the RPE-L and RPE-D values at specific physiological moments such as VAT and peak CPET were similar for both groups (FMS and $\mathrm{HC})$, we suggest that RPE can be an additional and efficient parameter for prescribing physical training for this population. Thus, the use of the Borg CR-10 scale should be encouraged as an additional parameter to guide the practice of physical activity, especially non-supervised aerobic exercises in patients with FMS. 


\section{CONCLUSION}

In conclusion, the results of this study showed that patients with FMS have higher RPE compared to healthy subjects. In addition, the Borg CR-10 scale scores obtained at VAT can be used as an additional parameter for prescribing exercise intensity in aerobic training protocols for women with FMS.

\section{REFERENCES}

1. Wolfe F, Smythe HA, Yunus MB, Bennett RM, Bombardier C, Goldenberg DL, et al. The american college of rheumatology 1990 criteria for the classification of fibromyalgia. Arthritis Rheum. 1990;33(2):160-72. doi: 10.1002/art.1780330203.

2. Homann D, Stefanello JMF, Góes SM, Leite N. Redução da capacidade funcional e exacerbação da dor durante o esforço do teste de caminhada de 6 minutos em mulheres com fibromialgia. Rev Bras Fisioter. 2011;15(6):474-80. doi: 10.1590/S1413-35552011000600008.

3. Furlan R, Colombo S, Perego F, Atzeni F, Diana A, Barbic $F$, et al. Abnormalities of cardiovascular neural control and reduced orthostatic tolerance in patients with primary fibromyalgia. J Rheumatol. 2005;32(9):1787-93.

4. Abeles AM, Pillinger MH, Solitar BM, Abeles M. Narrative review: the pathophysiology of fibromyalgia. Ann Intern Med. 2007;146(10):726-34. doi: 10.7326/0003-4819-146-10-200705150-00006.

5. Valim V, Oliveira LM, Suda AL, Silva LE, Faro M, Neto TL, et al. Peak oxygen uptake and ventilatory anaerobic threshold in fibromyalgia. J Rheumatol. 2002;29(2):353-7.

6. Zamunér AR, Andrade CP, Forti M, Marchi A, Milan J, Avila MA, et al. Effects of a hydrotherapy programme on symbolic and complexity dynamics of heart rate variability and aerobic capacity in fibromyalgia patients. Clin Exp Rheumatol. 2015;33(1 Suppl 88):S73-81.

7. Soriano-Maldonado A, Ortega FB, Munguía-Izquierdo D. Association of cardiorespiratory fitness with pressure pain sensitivity and clinical pain in women with fibromyalgia. Rheumatol Int. 2015;35(5):899-904. doi: 10.1007/ s00296-014-3203-z.

8. Hofmann P, Tschakert G. Special needs to prescribe exercise intensity for scientific studies. Cardiol Res Pract. 2010;2011:209302. doi: 10.4061/2011/209302.
9. Purvis JW, Cureton KJ. Ratings of perceived exertion at the anaerobic threshold. Ergonomics. 1981;24(4):295-300. doi: 10.1080/00140138108924852.

10. Zamunér AR, Moreno MA, Camargo TM, Graetz JP, Rebelo ACS, Tamburús NY, et al. Assessment of subjective perceived exertion at the anaerobic threshold with the Borg CR-10 Scale. J Sports Sci Med. 2011;10(1):130-6.

11. Forti M, Zamunér AR, Kunz VC, Salviati MR, Nery TAG, Silva E. Percepção subjetiva do esforço no limiar anaeróbio em pacientes com doença arterial coronariana. Fisioter Pesqui. 2014;21(2):113-9. doi: 10.1590/1809-2950/37321022014.

12. Borg G. An introduction to Borg's RPE scale. Ithaca: Movement Publications; 1985.

13. Craig $C L$, Marshall $A L$, Sjöström M, Bauman AE, Booth ML, Ainsworth BE, et al. International physical activity questionnaire: 12-country reliability and validity. Med Sci Sports Exerc. 2003;35(8):1381-95. doi: 10.1249/01. MSS.0000078924.61453.FB.

14. Wasserman K, Hansen JE, Sue DY, Casaburi R, Whipp BJ. Principles of exercise testing and interpretation: including pathophysiology and clinical applications. 3. ed. Philadelphia: Lippincott Williams and Wilkins; 1999.

15. Zamunér AR, Catai AM, Martins LEB, Sakabe DI, Silva E. Identification and agreement of first turn point by mathematical analysis applied to heart rate, carbon dioxide output and electromyography. Braz J Phys Ther. 2013;17(6):614-22. doi: 10.1590/S1413-35552012005000129.

16. Borg, G. Borg's perceived exertion and pain scales. Champaign: Human Kinetics; 1998.

17. Nielens H, Boisset V, Masquelier E. Fitness and perceived exertion in patients with fibromyalgia syndrome. Clin J Pain. 2000;16(3):209-13.

18. Pierrynowski MR, Tiidus PM, Galea V. Women with fibromyalgia walk with an altered muscle synergy. Gait Posture. 2005;22(3):210-8. doi: 10.1016/j.gaitpost.2004.09.007.

19. Tamburús NY, Kunz VC, Salviati MR, Castello Simões V, Catai $A M$, Silva E. Interval training based on ventilatory anaerobic threshold improves aerobic functional capacity and metabolic profile: a randomized controlled trial in coronary artery disease patients. Eur J Phys Rehabil Med. 2016;52(1):1-11.

20. Borg, G. Psychophysical bases of perceived exertion. Med Sci Sports Exerc. 1982;14(5):377-81.

21. Robertson RJ, Falkel JE, Drash AM, Swank AM, Metz KF, Spungen SA, et al. Effects of blood $\mathrm{pH}$ on peripheral and central signals of perceived exertion. Med Sci Sports Exerc. 1986;18(1):114-22. 